Barbara Rozmus, „Ja jestem” - moje „ja prawdziwe” czy moje „ja fatszywe”?

Tożsamośc cztowieka w środowisku cyfrowym na przyktadzie Instagrama,

[w:] Cztowiek w relacji do... Rozważania o cztowieku jako istocie relacyjnej,

red. Grzegorz Wąchol, Kraków 2020, s. 139-160.

DOI: http://dx.doi.org./10.15633/9788374388740.09

MGR BARBARA ROZMUS

\title{
"Ja jestem" - moje ,ja prawdziwe” czy moje „ja fałszywe"? Tożsamość człowieka w środowisku cyfrowym na przykładzie Instagrama
}

Człowiek jest istotą relacyjną. Tak został stworzony i bez względu na to, jak sam siebie postrzega, zawsze żyje w relacji: do świata, do drugiego, do siebie samego i wreszcie do Stwórcy. W czasie jego rozwoju może jednak się okazać, że na te relacje się zamyka, a tym samym - zamyka sobie drogę do życia autentycznie i w pełni, do czego każdego z nas powołał sam Bóg. Często zdarza się, że ludzie mają świadomość swojego funkcjonowania w relacji do świata, społeczności, drugiej osoby, a nawet do Boga. Wydawać się jednak może, że wielu ludzi nie do końca ma świadomość wymiaru relacji do siebie samego, oscylującej gdzieś pomiędzy relacją z drugą osobą i relacją z osobą Boga, choć uświadomienie jej sobie i zadbanie o nią jest absolutnie niezbędne do odkrycia w pełni swojej tożsamości, a także zrealizowania swojego ziemskiego powołania. Mając na uwadze ten brak w świadomości wielu ludzi, poparty również własnymi doświadczeniami poszukiwania tożsamości córki Bożej, postanowiłam poświęcić swoje rozważania właśnie relacji człowieka do siebie samego. $Z$ uwagi na dziennikarskie wykształcenie, a także funkcjonowanie od wielu lat w świecie 
cyfrowym mam głębokie przekonanie, iż wspomniany wymiar relacji człowieka do siebie samego bardzo mocno związany jest z przestrzenią mediów cyfrowych, stąd celem artykułu jest nie tylko przybliżenie zagadnienia tożsamości osoby, jej kreowania, ukazanie zależności między ,ja fałszywym” oraz ,ja prawdziwym” człowieka, ale przede wszystkim naświetlenie tych zagadnień w kontekście współczesnego człowieka sieci oraz zobrazowanie ich krótką obserwacją przeprowadzoną w obszarze jednego z najpopularniejszych na świecie portali społecznościowych - Instagrama.

\section{Tożsamość człowieka w kontekście duchowości chrześcijańskiej}

Podejmując refleksję nad zagadnieniem tożsamości, warto wskazać na jedno z najbardziej interesujących pytań, jakie ludzie zadawali sobie od wieków - kim jestem? Jak zauważa Halina Wantuła, można identyfikować siebie w różnych sferach, np. jako dziecko, żonę, filozofa, ekonoma, działacza, dochodząc w ten sposób do tej najbardziej uniwersalnej konkluzji - jestem człowiekiem. Może się wydawać, że jeśli człowiek pozbawi się w ten sposób swoich indywidualnych cech, zatraci się w tożsamości gatunku. Wantuła podkreśla jednak, że właśnie to pozorne zatracenie, uświadomienie sobie, że po prostu jestem, pozwala uchwycić cechę indywidualną jednostki, co z kolei sprawia, że człowiek w pełni otwiera się na ideę równości. Bardzo trafne wydaje się dalsze wyjaśnienie autorki: „Można by mówić o tożsamości, która wyraża się w świadomości, że jestem kimś innym od innych, i o tożsamości, która uświadamia, że jestem $z$ innymi jedno"'. Tożsamość można zatem zdefiniować jako

1 H. Wantuła, Refleksje nad tożsamościq, w: Dylematy tożsamości. Stare i nowe konteksty socjalizacji, red. Z. Pucek, Kraków 2007, s. 75. 
„zespół wzajemnie powiązanych cech, które jednostka przypisuje samej sobie"2. Wantuła, omawiając pojęcie tożsamości, wskazuje także na dwie kategorie, które mieszczą się w obrębie tego zjawiska: tożsamość złożoną ze zmiennych wizerunków siebie samego (związaną z rolami i sytuacjami społecznymi) oraz tożsamość będącą trzonem osoby (dotyczy trwałych elementów wizerunku i w niej zawiera się odpowiedź na pytanie: „Kim jestem?”) 3 .

Analizując zagadnienie tożsamości osoby, nie sposób nie rozważyć go na płaszczyźnie duchowej, odwołując się tym samym do prawd odwiecznych, które przedstawię na gruncie duchowości chrześcijańskiej. Konstrukcja tytułu tego artykułu nie jest przypadkowa. Już pierwsza jego część - ,ja jestem” - nawiązuje do słowa Bożego, które bardzo mocno do mnie przemawia, czyli do określenia użytego przez samego Jezusa w celu objawienia swojej tożsamości. Jak zauważa o. Paweł Klimczak, w Ewangelii znajdują się cztery formuły absolutne, których używa Jezus, mówiąc do swoich uczniów o sobie, a przykładem jednej z nich niech będzie następujący cytat z Ewangelii św. Jana wskazany przez dominikanina: „Zaprawdę, zaprawdę, powiadam wam: Zanim Abraham stał się, JA JESTEM"4. Tożsamość Chrystusa przedstawiona w ten sposób, a także zapis tej formuły odnoszą się do Starego Testamentu i zdają się mieć fundament w wieczności. Co więcej, słowa te czytane dzisiaj wskazują na istnienie osoby Jezusa nieprzerwanie także w teraźniejszości. Choć w Ewangelii znajdują się jeszcze trzy dodatkowe formuły absolutne, a także

2 H. Wantuła, Refleksje..., dz. cyt., s. 76.

3 Por. H. Wantuła, Refleksje..., dz. cyt., s. 76.

4 J 8, 58; cyt. za: P. Klimczak, Chrystologia 11. Chrystus w Ewangelii św. Jana. Cz. II: Formuty ,Ja jestem", http://www.szkolateologii.dominikanie.pl/ summa/chrystologia-11-chrystus-w-ewangelii-sw-jana-cz-ii-formuly-ja-jestem/ (22.06.2019). 
liczne formuły dookreślone ${ }^{5}$, to jednak właśnie formuła absolutna - JA JESTEM - wydaje się w pełni ukazywać tożsamość doskonałego Człowieka, umiłowanego Syna Bożego, który w pełni zjednoczony jest z Ojcem. Określenie siebie w ten sposób przez Jezusa również w mojej ocenie, ukształtowanej na bazie poznania rozumowego oraz doświadczenia wyniesionego z modlitwy opierającej się na słowie Bożym, wydaje się wskazywać na realną obecność doskonałej Osoby nieprzerwanie w każdej chwili i każdym miejscu, bez możliwości zamknięcia jej w jakichkolwiek ramach czasowych, przestrzennych czy wyobrażeniowych. Z kolei formy dookreślone, o których wspomina o. Klimczak, np. „Ja jestem drogą i prawdą, i życiem”, „Ja jestem światłością świata”, czy też pozostałe nauczanie Jezusa zawarte w Ewangelii wskazują na potrzebę poznawania Boga, stawania w Jego obecności, co równa się ze stawaniem w doskonałej obecności Osoby Boskiej - „Ja jestem”. Idąc dalej w tych rozważaniach, można dojść do wniosku, że bycie z Bogiem, który jest miłością, ma prowadzić człowieka do przebóstwienia. Monika i Marcin Gajdowie, chrześcijańscy terapeuci, w swojej książce Rozwój. Jak wspótpracować z taska? podkreślają, iż celem rozwoju człowieka jest miłość, a jeśli się pojmie, że to Bóg jest miłością, jasne powinno stać się, iż pełnią tego rozwoju jest udział człowieka w wewnętrznym życiu Boga7. Wówczas człowiek wchodzi coraz głębiej w swoją tożsamość jako osoby stworzonej na obraz Boga; gdy żyje w sferze ,ja prawdziwego”, będąc kształtowany przez Ducha Bożego, może dążyć do upragnionej doskonałości. Doskonała obecność osoby Boga prowadzi zatem człowieka do autentycznego bycia tym, kim jest i kim ma się

5 Por. P. Klimczak, Chrystologia 11, dz. cyt.

6 J 14, 6; J 8, 12; cyt. za: P. Klimczak, Chrystologia 11, dz. cyt.

7 Por. M. Gajda, M. Gajda, Rozwoój. Jak wspótpracować z taskq̨?, Szczecin 2012, s. 15. 
stawać. Rodzi się we mnie przekonanie, że w relacji człowieka do siebie samego chodzi o to, by określając swoją tożsamość, w pełni prawdziwie i z pełnią mocy miłości mógł on na wzór Jezusa użyć słów „ja jestem”, dookreślając swoją tożsamość tak, jak chce tego Bóg, czyli jako bycie córką lub synem Boga.

\section{Od „ja fałszywego" do „ja prawdziwego”}

Czym zatem jest ,ja prawdziwe”, w którym zgodnie z przeznaczeniem powinniśmy żyć? Tak naprawdę rzeczywistość kryjąca się pod terminem ,ja” nie jest w pełni uchwytna i wciąż stanowi tajemnicę dla badaczy ludzkiej osobowości. Henryk Suszek opisuje „ja” jako złożoną i dynamiczną strukturę poznawczą zajmującą centralne miejsce w osobowości, odgrywającą główną rolę w regulacji rozmaitych procesów psychicznych, poznawczych, emocjonalnych, motywacyjnych i behawioralnych ${ }^{8}$ Z kolei Bogdan Wojciszke zauważa, że ludzie, choć doświadczają swojego ,ja”, nie są w stanie opisać, czym ono jest. Z pewnością „ja” podejmuje decyzje, tworzy relacje z innymi ludźmi, jest uświadamiane, poznawane i doświadczane. Kształtuje się ono od około drugiego roku życia, kiedy dziecko zaczyna rozpoznawać siebie ${ }^{9}$. Bardzo wartościowe w próbie zrozumienia zagadnienia tożsamości człowieka jest nauczanie Moniki i Marcina Gajdów, stanowiące zbiór poglądów z pogranicza psychologii i duchowości oraz doświadczeń wyniesionych

8 Por. H. Suszek, Różnorodność wielości Ja, „Roczniki Psychologiczne” 10 (2007) nr 2, https://www.kul.pl/files/1024/Roczniki_Psychologiczne/2007/2/Roczniki_Psychologiczne_t._10_2007_nr_2_7-37_SUSZEK. $\operatorname{pdf}(24.10 .2019)$.

9 Por. Rozumienie siebie... czyli w jaki sposób poznajemy samych siebie, https:// ssl-kolegia.sgh.waw.pl/pl/KES/struktura/IFSISE/struktura/ZS/zaklad/ sklad/Documents/5.Rozumienie_siebie.pdf (24.10.2019). 
z bezpośredniej pracy terapeutycznej z ludźmi. „Ja prawdziwe» jest potencjalną pojemnością na łaskę"10 - taką definicję omawianej formuły podają wspomniani terapeuci. Jak wyjaśniają, drogą do świętości człowieka jest tak pełne otwarcie się na łaskę, by uczestnicząc w życiu Chrystusa, stać się nim samym. Autorzy podkreślają jednak, że wbrew temu, co odnaleźć można w zbiorze poglądów New Age, drogą dla człowieka nie jest odkrycie swojego uśpionego potencjału boga, lecz darmowe przyjęcie łaski i współpraca z nią przy pomocy modlitwy, ascezy, a także miłości bliźniego. Jest to bardzo istotna różnica, o której nie można zapomnieć. Otwarcie na łaskę i przyjęcie jej jest przestrzenią w sercu człowieka, w której rodzi się miłość, jest przestrzenią ,ja prawdziwego”. Właśnie w tej sferze istnienia człowiek ma kontakt z własną wartością, która nie podlega budowaniu, a zanurzona jest w nieskończoności ${ }^{11}$. Gajdowie tłumaczą to w następujący sposób: „Używając współczesnych obrazów, możemy powiedzieć, że JA PRAWDZIWE jest niczym link, którym możemy wejść w wieczność, ciągle jeszcze żyjąc w czasie"12. Co więcej, życie w obszarze „ja prawdziwego" charakteryzuje się wolnością od siebie samego oraz okoliczności zewnętrznych. Człowiek taki odkrywa życie wewnątrz siebie i nie potrzebuje zakładać żadnych masek, co prowadzi go do wolności od opinii ludzkich, sukcesu, sławy czy nadmiernego troszczenia się o swoje zdrowie. Odkrywa on swoją wartość, tożsamość, widzi własne piękno, co przyczynia się do tego, że może w pełni rozwijać swoje zdolności i talenty. Może kochać innych i służyć im, odnajdując swoje miejsce w rodzinie ludzkiej ${ }^{13}$. Tak przedstawiona wizja tożsamości człowieka oraz drogi do jej przyjęcia powinna

10 M. Gajda, M. Gajda, Rozwoój, dz. cyt., s. 63.

11 Por. M. Gajda, M. Gajda, Rozwój, dz. cyt., s. 64-65.

12 M. Gajda, M. Gajda, Rozwoój, dz. cyt., s. 65.

13 Por. M. Gajda, M. Gajda, Rozwoój, dz. cyt., s. 65. 
być oczywiście dla niego naturalna i przez niego upragniona. Losy ludzkie są jednak znacznie bardziej pogmatwane, dlatego też na drodze do autentycznej pełni pojawiają się przeszkody, nierzadko obecne w nas samych.

Kolejnym punktem prowadzącym przez podjęte przeze mnie rozważania niech będzie wyjaśnienie drugiego określenia celowo przeciwstawionego w tytule formule ,ja jestem”, czyli ,ja fałszywe”. Jak podkreślają Gajdowie: „Zostaliśmy stworzeni, by być szczęśliwymi ludźmi"14. Poszukujemy szczęścia zarówno w relacjach, jak i w aktywności zawodowej, pasjach, zabawie, podróżach. Istnieje niezliczona ilość dróg wspomnianych poszukiwań, zgodna z niezliczoną ilością osób, które je podejmują. Jednak jak pokazuje rzeczywistość, to poszukiwanie szczęścia wychodzi nam różnie. Nierzadko związane jest ono z pomyłkami, błądzeniem, zranieniami i cierpieniem. Trudno nie spostrzec, jak wielu ludzi korzysta obecnie z pomocy psychologów, psychiatrów, terapeutów. Niemalże powszechnie spotykane stały się depresje, zaburzenia osobowości, zaburzenia lękowe czy choroby psychiczne. Masowo pojawia się kryzys tożsamości. Obserwując ludzi w otaczającej rzeczywistości, łatwo dojść do wniosku, że bardzo często te próby odnalezienia szczęścia nie są skuteczne, co więcej, przynoszą wiele szkód, prowadząc do całkowitej utraty kontaktu $z$,ja prawdziwym”. Ludzie najczęściej nieświadomie tworzą przy tym fałszywą tożsamość, która odgradza ich od autentycznego życia. Gubiąc się w świecie, w relacjach, w sobie samych, wytwarzają struktury ,ja fałszywego”, którego funkcjonowanie niczym mur obronny miasta odgradza człowieka od prawdziwego przeżywania siebie samego w każdym wspomnianym na początku artykułu obszarze relacji. W ten sposób człowiek zostaje odgrodzony od doświadczenia prawdziwego szczęścia, którego pragnie i usilnie poszukuje.

14 M. Gajda, M. Gajda, Rozwój, dz. cyt., s. 39. 
Czym zatem jest wspomniana fałszywa tożsamość? Spróbujmy krótko przyjrzeć się temu zagadnieniu. Ojciec Thomas Keating określa ,ja fałszywe” w następujący sposób:

„Fałszywe ja” jest współczesnym synonimem tego, co apostoł Paweł nazywa w Listach „dawnym człowiekiem”. To świadomość naszej tożsamości, będącej zbiorem przyzwyczajeń, które wyhodowaliśmy, realizując nasz emocjonalny program na szczęście, i które utrwaliły się w nas w formie, nazwijmy je, centrów energetycznych. Pełnią one rolę środków ciężkości i centralnych punktów odniesienia dla naszych wyobrażeń, pamięci, pragnień, uczuć i chęci. Możemy je nazwać centrum przyciągania, gdzie „ja” jest jego jądrem ${ }^{15}$.

Dalej stwierdza on:

W miejsce Boga, jako centrum wszelkiej egzystencji, fałszywe ,ja” rodzi tożsamość egotyczną. Wszystko musi służyć ego. Cokolwiek dostaje się w sferę jego oddziaływania, nie jest postrzegane z perspektywy obiektywności i swojej własnej rzeczywistości, lecz oceniane jest w kontekście przydatności do realizacji emocjonalnego programu na szczęście, zawierającego w sobie potrzebę bezpieczeństwa, kontroli oraz rozpaczliwe dążenie do akceptacji ${ }^{16}$.

„Fałszywe ja” jest zatem nieprawdziwą tożsamością człowieka składającą się z mechanizmów obronnych, odgradzającą go od siebie samego, bliźniego i Boga oraz pozbawiająca go możliwości nawiązywania owocnych relacji. Konsekwencjami tego stanu są zawężenie świadomości i utrata kontaktu z rzeczywistością (w mniejszym lub większym stopniu) $)^{17}$.

Wiedząc już o istnieniu dwóch przeciwstawnych ,ja”, z których jedno jest autentyczną tożsamością człowieka, zanurzoną

15 T. Keating, Fatszywe „ja” - prawdziwe ,ja”, http://www.wccm.pl/index. php?id=441 (22.06.2019).

16 T. Keating, Fatszywe ,ja”..., dz. cyt.

17 Por. M. Gajda, M. Gajda, Rozwój, dz. cyt., s. 45. 
w tożsamości Boga, a drugie jedynie upozorowanym zlepkiem zakładanych masek, warto zadać sobie pytanie: co dalej, jaka jest droga do siebie samego? Wanda Półtawska w Beskidzkich rekolekcjach zawarła wypowiedź księdza Karola Wojtyły, która może być wskazówką do odpowiedzi na postawione przeze mnie pytanie: „Trzeba poznać siebie, wydobywać wszystko z podświadomości, żeby wszystko było jasne i proste"18. Gajdowie wspominają natomiast, jak ojciec święty Jan Paweł II podczas jednego ze spotkań z młodymi ludźmi powiedział do nich: „Odkryć własną tożsamość to bardzo trudne zadanie. Być tym, kim powinno się być”19. Trudno nie odnieść wrażenia, że troska papieża Polaka o młodych ludzi i jego świadomość trudu związanego z odkrywaniem przez nich swojej tożsamości była ogromna. Co więcej, Gajdowie wspominają, jak św. Jan Paweł II, zapytany o najważniejsze według niego zdanie z Biblii, wskazał słowa z Ewangelii św. Jana: „Poznacie prawdę, a prawda was wyzwoli”" ${ }^{20}$. Nie sposób nie przywołać w tym miejscu wywiadu z Danutą Rybicką, przyjaciółką papieża Polaka, który przeprowadziłyśmy wraz z koleżankami jeszcze na studiach. Była to rozmowa, której fragmenty wykorzystałyśmy w pierwszym zrealizowanym przez nas materiale telewizyjnym, wyemitowanym oczywiście w studenckiej telewizji JP2TV. Danuta Rybicka w odpowiedzi na zadane przeze mnie pytanie dotyczące pragnień już nieżyjącego papieża Polaka wobec młodych ludzi wzruszona powiedziała: „Myślę, że chciałby prawdy od was. Jeśliby on dziś czegoś chciał od młodzieży, to prawdy, żeby postępowali zgodnie z prawdą, która jest zawarta w przykazaniach, w Ewangelii,

18 W. Półtawska, Beskidzkie rekolekcje. Dzieje przyjaźni księdza Karola Wojtyty z rodzinq Póttawskich, Częstochowa 2009, s. 69.

19 M. Tomczak, Odkryć wtasna tożsamośc - to bardzo trudne zadanie..., https:// www.deon.pl/slub/homilie-slubne/art,2, odkryc-wlasna-tozsamosc-to-bardzo-trudne-zadanie-.html (24.06.2019).

20 J 8, 32; cyt. za: M. Gajda, M. Gajda, Rozwój, dz. cyt., s. 70. 
w prawie naturalnym"21. Obraz wyłaniający się z przytoczonych wskazań to droga prawdy, którą człowiek musi podjąć, aby stać się sobą. W tym miejscu nie sposób jeszcze raz nie przytoczyć słów samego Jezusa z Ewangelii św. Jana: „Ja jestem drogą i prawdą, i życiem. Nikt nie przychodzi do Ojca inaczej, jak tylko przeze mnie"22. Zmierzając do wieczności, gdzie na człowieka czeka miłujący Bóg, należy więc wyruszyć w drogę. Jest to droga poszukiwania, poznawania, przyjęcia i odwzajemnienia miłości Jezusa Chrystusa. Gajdowie, opierając się na tekście Ewangelii, wskazują na pewną zależność: „Jeśli ja fałszywe nie obumrze, nie będziesz zdolny do miłości, czy też kto chce zachować ja fałszywe, ten straci ja prawdziwe"23. Terapeuci podkreślają, że człowiek chcący się rozwijać musi stoczyć walkę z ukrywającym się przeciwnikiem, którym określają ,ja fałszywe”. Drogą do wygranej jest poznanie strategii tego przeciwnika oraz wdrożenie środków zaradczych ${ }^{24}$. Można mieć jednak pewność, że decyzja wyruszenia w tę podróż oznacza, że człowiek nigdy nie pozostanie w niej osamotniony, a Duch Boży w nim mieszkający doprowadzi go do prawdy. Co więcej, Gajdowie za Katechizmem Kościoła katolickiego przytaczają wspaniałą formułę brzmiącą: „Bóg stał się człowiekiem, aby człowiek mógł stać się Bogiem”25. Możemy mieć zatem pewność, że Bóg pragnie, aby jego łaska przebóstwiła każdego człowieka aż do zjednoczenia z nim, tak aby nasza tożsamość wyrażała się w stwierdzeniu „Jestem córką Boga” lub „Jestem synem Boga”, czyli w ,ja prawdziwym”, bez żadnych zbędnych dodatków czy zafałszowań.

21 D. Rybicka, Mtodzi Jana Pawta II, https://www.youtube.com/watch?v=rIm6eBROEdU (22.06.2019).

$22 \mathrm{~J} 14,6$.

23 M. Gajda, M. Gajda, Rozwój, dz. cyt., s. 113.

24 Por. M. Gajda, M. Gajda, Rozwój, dz. cyt., s. 69.

25 Katechizm Kościota katolickiego, 460; cyt. za: M. Gajda, M. Gajda, Rozwój, dz. cyt., s. 69. 


\section{Dylematy związane z tożsamością i autokreacją własnej osoby w sieci}

Odkrycie swojej tożsamości, a także kreowanie jej w sposób autentyczny ma szczególne znaczenie w przypadku osób młodych. Młodość jest okresem życia, w którym rozluźniają się więzi z rodzicami i najbliższymi, a młody człowiek, wychodząc do świata, poszerza horyzonty myślenia, nawiązuje nowe relacje i często staje wobec wyzwania zachowania, dookreślania czy odnalezienia na nowo swojej tożsamości, a także kształtowania jej we współpracy z łaską Bożą. Jak zauważa Ewa Wysocka, autokreacja osoby najpierw dokonuje się przez naśladowanie innych, by następnie przeobrazić się $\mathrm{w}$ świadome kreowanie siebie na podstawie racjonalnie wybranych wzorów osób. Autorka podkreśla również znaczenie rozwiązania problemów związanych z kryzysem tożsamości młodej osoby. Proces omawianej autokreacji obejmuje odtworzenie i zrozumienie własnej przeszłości, aby świadomie pojąć siebie i swoje funkcjonowanie w teraźniejszości, przy czym równie ważne są zdolność kreowania własnej przyszłości i posiadanie wizji, jak ma ona wyglądać. Bardzo znacząca w procesie tym jest percepcja siebie samego, która obejmuje samoświadomość, autoafirmację, poczucie swojej wartości, a także samookreślenie ${ }^{26}$. Współcześnie życie codzienne niemal każdego młodego człowieka przenika świat wirtualny. Nieuniknione wydaje się więc rozpatrywanie zagadnienia w kontekście środowiska cyfrowego. Wpływ Internetu na tożsamość użytkowników jest niepodważalny, ale wcale nie jednoznaczny. Jak zauważa Aleksandra Wysokińska, jest wiele podejść do tej tematyki, spośród których badaczka podkreśla następujące: Internet czyni tożsamość

26 Por. E. Wysocka, Doświadczenie życia w mtodości-wyznaczniki, dylematy tożsamościowe i strategie pokonywania mtodzieńczego kryzysu rozwojowego, w: Dylematy tożsamości. Stare i nowe konteksty socjalizacji, dz. cyt., s. 129. 
bardziej płynną, co oznacza, że granice tożsamości są elastyczne, a pojęcie ,ja prawdziwego" przestaje być oczywiste; tożsamość pod wpływem Internetu ulega zwielokrotnieniu - różnorodność sytuacji społecznych i przyjmowanych ról, a także słabość więzi charakteryzująca środowisko wirtualne sprawiają, że tożsamość nie tworzy spójnej całości i jest niejednolita; Internet wpływa na integrację tożsamości, a przyczynia się do tego wielość możliwości jednoczenia się z innymi użytkownikami na podstawie np. wspólnych zainteresowań, cech itp. Ostatnie wspomniane podejście zakłada, iż możliwe jest harmonijne kreowanie tożsamości offline i online. Wpływ Internetu na tożsamość zmieniał się jednak na przełomie lat. W początkowym okresie pojawiło się zjawisko „zakładania masek" przez użytkowników, którzy korzystali z możliwości manipulowania własnym wizerunkiem, jakie stwarza Internet. Co więcej, przeniesienie znacznej części codziennego życia do świata wirtualnego znacząco ograniczyło komunikację niewerbalną i zminimalizowało przy tym fizyczne kontakty społeczne. Specyfika tego środowiska pozwala także uczynić siebie kimś wyjątkowym, pięknym, barwnym, ciekawym, co często nie jest współmierne z rzeczywistością. Warto w tym miejscu wspomnieć również o nowym typie tożsamości określanej jako insert. Charakteryzuje ją otwarcie na wszelkie materiały będące w jej zasięgu, mające wpływ na jej ukształtowanie się. Przestrzeń wirtualna, która daje nieograniczone możliwości aktualizacji i archiwizacji informacji, z pewnością sprzyja rozwojowi tego typu tożsamości ${ }^{27}$.

W procesie autokreacji własnej osoby bardzo istotną rolę odgrywają portale społecznościowe, zwłaszcza te, których użytkowanie polega na tworzeniu swoich własnych profili. Na potrzeby tych

27 Por. A. Wysokińska, Wptyw Internetu na przemiany tożsamości we wspótczesnym śrwiecie, w: Zaplątani w sieci. Spoteczeństwo wobec wyzwań nowych mediów, red. K. Piech i in., Toruń 2017, s. 265-269. 
rozważań ograniczyłam się do krótkiego zanalizowania Instagrama, który wydaje się mieć szczególne znaczenie w prezentowaniu siebie w social mediach. Człowiek, kreując siebie w sieci, kreuje w pewien sposób swoją tożsamość. Będąc osobą z pokolenia już w dużej mierze zanurzonego w świecie cyfrowym, obserwuję wiele przypadków działań młodych osób w tej przestrzeni, które doprowadziły mnie w trakcie opracowywania omawianego tematu do postawienia sobie wielu pytań, spośród których można wymienić np. następujące: kto jest obecny na wielu spośród tych profili w social mediach, a zwłaszcza na Instagramie? Czy rzeczywiście są to autentyczne osoby? Czy ludzie kreujący w ten sposób siebie w ogóle wiedzą, kim są? Jaki jest cel prezentowania siebie w ten, a nie inny sposób w mediach społecznościowych i co kieruje młodymi ludźmi korzystającymi z Instagrama? Czy poszczególne profile są jedynie przejawem zabawy albo nieszkodliwym podążaniem za trendami, czy może mają realny wpływ na relację osoby do siebie samej, a także na obserwujących dany profil, a jeśli tak, to czy wpływ ten nie zagraża prawdziwej tożsamości człowieka, a tym samym nie stoi na przeszkodzie w drodze do świętości?

\section{Wpływ ciszy na autentyczność osoby w środowisku cyfrowym}

Często odkrywanie swojej tożsamości na nowo można odnieść do ludzi młodych, którzy stają przed decyzjami dotyczącymi swojego powołania czy też rozpoczynają samodzielne życie. Jak wynika z wcześniejszych rozważań, drogą do autentycznego życia w swojej prawdziwej tożsamości jest spotkanie z Jezusem. Opierając się na wielu świadectwach, a także na własnych doświadczeniach duchowych, mogę stwierdzić, że choć Bóg może w każdej chwili i w każdym miejscu poruszyć serce człowieka, objawiając mu swoją 
miłość, to jednak człowiek jest w stanie sam stworzyć warunki dla Bożego działania. Bardzo często konieczna do zjednoczenia z sobą samym, a w następstwie - do autentycznego życia i zjednoczenia ze Stwórcą, jest przestrzeń ciszy. Papież Benedykt XVI zwraca uwagę, iż relacja $\mathrm{z}$ Bogiem powinna być przeżywana w sposób analogiczny do relacji z najbliższymi osobami. Chodzi w niej o zwyczajne stawanie $\mathrm{w}$ obecności Boga, bycie z Nim jak z przyjacielem ${ }^{28}$. Papież $\mathrm{w}$ następujący sposób podkreśla w tym aspekcie znaczenie ciszy:

Dlatego też modlitwa chrześcijańska polega na nieustannym wpatrywaniu się ciągle w nowy sposób w Chrystusa, na rozmawianiu z Nim, wspólnym przebywaniu w milczeniu, słuchaniu Go, działaniu i cierpieniu z Nim. Chrześcijanin odkrywa na nowo swoją prawdziwą tożsamość w Chrystusie, „pierworodnym z każdego stworzenia”, w którym wszystko zostało stworzone. Utożsamiając się z Nim, będąc z Nim jedno, odkrywam na nowo moją tożsamość, tożsamość prawdziwego syna, który wpatruje się w Boga jako Ojca pełnego miłości ${ }^{29}$.

Mając świadomość, jak elitarnym zjawiskiem we współczesnej rzeczywistości jest cisza, mająca niebagatelne znaczenie w procesie odnalezienia własnej tożsamości, nietrudno wywnioskować, że obecnie będzie to wielkie wyzwanie. Dzisiejszy świat przepełniony bodźcami nie stanowi przestrzeni, która umożliwia wejście w ciszę, utrudnia też słuchanie. Bardzo znacząca liczba tych bodźców bezpośrednio związana jest $\mathrm{z}$ intensywną obecnością mediów w życiu codziennym człowieka. Należy w tym miejscu wyeksponować zwłaszcza wpływ rozwoju mediów społecznościowych i nowych technologii na życie ludzkie, umożliwiających niemalże

28 Por. Benedykt XVI, Modlitwa miejscem odkrywania swojej tożsamości-katecheza Benedykta XVI z 3 października 2012, https://www.oaza.p1/cdm/ strefa-modlitwy/katechezy-benedykta-xvi-o-modlitwie/45-modlitwa-miejscem-odkrywania-swojej-tozsamosci-katecheza-benedykta-xvi-z-3-pazdziernika-2012 (24.06.2019).

29 Benedykt XVI, Modlitwa miejscem odkrywania swojej tożsamości..., dz. cyt. 
przeniesienie naszego „tu i teraz”, czyli bycia i życia, do sieci. Jak w adhortacji Christus vivit zauważa papież Franciszek:

Cechą współczesnego świata jest środowisko cyfrowe. Znaczna część ludzkości jest w nim stale i codziennie zanurzona. Nie chodzi już tylko o „używanie” narzędzi komunikacji, ale o życie w kulturze głęboko skomputeryzowanej, która ma bardzo mocny wpływ na pojęcie czasu i przestrzeni, na postrzeganie siebie, innych i świata, na sposób komunikowania, uczenia się, zdobywania informacji, nawiązywania relacji z innymi. Podejście do rzeczywistości, które ma skłonność do faworyzowania obrazu, a nie słuchania i czytania, wpływa na sposób uczenia się i rozwój zmysłu krytycznego ${ }^{30}$.

Jak wynika ze spostrzeżeń Franciszka, postrzeganie człowieka zanurzonego $\mathrm{w}$ świecie cyfrowym zależne jest od tego, co $\mathrm{z}$ tego świata czerpie. Można zatem wywnioskować, że również wszelkie relacje w pewien sposób będą z tego wynikać, w tym relacja osoby do siebie samej. Wartą podkreślenia wydaje mi się również obserwacja braku autorytetów potrzebnych do prawidłowego rozwoju młodego człowieka, co związane jest z kryzysem tożsamości, który ma daleko idący negatywny wpływ (rozpad rodziny, zaburzenia w rolach rodzicielskich, utrata autorytetu w środowisku kościelnym itp.). Ten, można by uznać, zamknięty krąg kryzysu tożsamości bezpośrednio wiąże się z poszukiwaniem wzorców niejako na oślep, często w przestrzeni mediów, zwłaszcza tych najbardziej popularnych wśród młodych osób - mediów społecznościowych. Tam odbieranie obrazu innych osób i przede wszystkim tworzenie własnych profili staje się bardzo istotnym elementem towarzyszącym osobie w procesie odkrywania własnej tożsamości. Można niestety odnieść wrażenie, że nierzadko działania te hamują omawiany proces i zatrzymują osobę w pułapce „ja fałszywego”. Benedykt XVI w orędziu na Światowy Dzień Środków Społecznego Przekazu z 2013 roku zaznaczył, że w sieci oprócz przekazywania informacji

30 Franciszek, Christus vivit, 86. 
przekazujemy samych siebie, dlatego powinniśmy być autentyczni. Poruszył on również aspekt popularności w sieci, która często stoi ponad wiarygodnością, co grozi zniekształceniem odbioru rzeczywistości ${ }^{31}$. Jak z kolei wskazuje Franciszek: „Istnieją świadectwa przydatne, by nas pobudzić i motywować, ale nie dzięki temu, że próbujemy je kopiować, gdyż to mogłoby nas jeszcze oddalić od wyjątkowej i specyficznej drogi, jaką przygotował dla nas Pan; stawać się świętym to stawać się pełniej sobą, być tym, co Bóg zechciał wymarzyć i stworzyć, a nie kserokopią" ${ }^{32}$. Ma to szczególne znaczenie w przypadku osób młodych, które przecież są na etapie kształtowania własnej osobowości, szukania siebie, swojej drogi życiowej, a to właśnie one są grupą najczęściej użytkującą media społecznościowe, zwłaszcza Instagram.

\section{W świecie Instagrama - wzniosłe cele, prymitywna rzeczywistość}

Z uwagi na ogrom informacji i zjawisk w przestrzeni social mediów, które związane są z podjętą tematyką, a także mając na uwadze ograniczony zakres tych rozważań, przeprowadziłam jedynie krótką obserwację użytkowników Instagrama. Poszukując odpowiedzi na pytania dotyczące roli mediów społecznościowych w odkrywaniu tożsamości człowieka i jego „prawdziwego ja”, postanowiłam przyjrzeć się zdjęciom i profilom na Instagramie. Najpierw jednak warto krótko odnieść się do założeń portalu.

31 Por. Benedykt XVI, Portale spotecznościowe: bramy prawdy i wiary; nowe przestrzenie dla erwangelizacji. Orędzie papieża Benedykta XVI na 47. Światowy Dzień Środków Spotecznego Przekazu, Watykan 2013, https://www. paulus.org.p1/220,47-sdssp-benedykt-xvi-2013 (24.06.2019).

32 Franciszek, Christus vivit, 162. 
Tłumaczenie nazwy tego serwisu wyjaśnia cel jego powstaniachodzi o natychmiastowe udostępnienie zdjęcia, które właśnie zostało zrobione. Interpretując to założenie, można wywnioskować, że Instagram powstał po to, by zatrzymywać momenty za pomocą zdjęcia i natychmiast udostępniać je innym. Chodziło zatem o uchwycenie ulotnych momentów i dzielenie się nimi z użytkownikami za pośrednictwem swojego indywidualnego profilu, przypominającego pamiętnik. Rożne funkcje dodatkowe Instagrama, takie jak np. filtry na zdjęcia, miały pomagać w tworzeniu niepowtarzalnych fotografii i niejako sztuki ${ }^{33}$. Współcześnie można jednak zauważyć znaczne różnice między założeniami, które miał spełniać portal, oraz początkami działań jego użytkowników a jego przestrzenią dziś. Niestety choć Instagram wciąż jest udoskonalany w nowe opcje, a co za tym idzie stwarza nowe możliwości, choćby autopromocji, wydaje się internetową sceną teatru masek zakładanych przez użytkowników.

Podejmując obserwację użytkowników, pozwoliłam sobie zawęzić grono przeglądanych profili do kobiecych. Uznałam, że warto przyjrzeć się profilom nieznanych mi młodych kobiet, a także zdjęciom kobiet świętych lub żyjących w sposób święty, czyli tych, których „ja prawdziwe” trwało w Chrystusowym JA JESTEM. Kierowana ciekawością, wpisałam na Instagramie także słowa kluczowe z hasztagami takie jak: \#kobiecość, \#autentyczność, \#naturalność, \#polishgirl, \#polishwoman, czyli słowa, które z punktu widzenia zagadnienia tożsamości młodych kobiet oraz użytkowników Instagrama mają istotną wartość poznawczą. Pozwoliło mi to przyjrzeć się zamieszczanym pod nimi zdjęciom.

Moją uwagę skupiłam na komunikacji niewerbalnej kobiet $\mathrm{z}$ analizowanych zdjęć. Wizerunek wielu użytkowniczek Instagrama

33 Por. Co to jest Instagram? Powstanie, rozwoój aplikacji. Rejestracja, https:// www.erainformatyki.pl/instagram.html (23.10.2019). 
nie jest naturalny. Łatwo dostrzec ukrywanie twarzy za mocnym makijażem, usta często ułożone w tzw. dziubek, szeroko otwarte oczy, niemal doskonale ułożone włosy - to cechy charakterystyczne dla niezliczonej liczby kobiecych selfie na Instagramie. Brak z kolei blasku w oczach i uśmiechu radości na twarzy, które łatwo dostrzec na zdjęciach kobiet z pewnością żyjących autentycznie oraz świętych, np. Heleny Kmieć, bł. Chiary Luce Badano czy św. Joanny Beretty Moli. Spojrzenie w przypadku wymienionych kobiet jest łagodne, ciepłe i jasne, a na zdjęciach wielu innych użytkowniczek - jakby puste, nieniosące żadnego przekazu. Często na fotografiach na pierwszy plan wysuwają się fizyczność i cielesność. Trudno np. domyślić się, co może być celem autorki zamieszczającej zdjęcie dziecka ukazanego na tle jej krocza w samej bieliźnie, niemniej z pewnością wspomniane zdjęcie nie wskazuje na takie wartości w macierzyństwie jak miłość, czułość, radość. Jeśli chodzi o zdjęcia wyszukane na Instagramie oznaczone hasztagami \#naturalność czy \#autentyczność, to niestety w dużej mierze nie mają one $z$ tymi pojęciami nic wspólnego. Nie sposób w tym miejscu tłumaczyć, jak definiujemy słowa „kobiecość”, „naturalność” bądź „autentyczność”, ale niestety wydaje się, że wiele spośród użytkowniczek nie ma pojęcia, co one oznaczają. Dodając pozowane zdjęcia selfie, eksponujące często ich fizyczność i seksualność, oznaczają je hasztagami ze wspomnianymi słowami. Co więcej, można odnieść wrażenie, że osoby na tych zdjęciach różnią się jedynie kolorem włosów, ubraniem czy nałożonym na fotografię filtrem. Nie ma to nic wspólnego z autentycznością i naturalnością. Jest to u młodych kobiet bardzo niepokojące zjawisko, gdyż wskazuje na brak świadomości siebie samych, tego, kim są i kim mają się stawać, oraz na brak refleksji nad sensem swojego działania. Opisana obserwacja jest jedynie małym wycinkiem ze świata Instagrama, którego szersza analiza mogłaby posłużyć do napisania obszernej pracy naukowej. 


\section{Jaką drogą do siebie samego?}

Podsumowując treść tych rozważań, warto odpowiedzieć na zamieszczone wcześniej pytania. Po przeprowadzeniu krótkiej obserwacji profili kobiecych na Instagramie można wyciągnąć wiele wniosków, które odnoszą się do znacznej części użytkowników w ogóle, bez względu na płeć. $Z$ pełnym przekonaniem należy stwierdzić, że na wielu spośród tych profili nie są przedstawione autentyczne osoby. Młodzi ludzie kreujący swoją tożsamość przy użyciu instagramowego profilu nierzadko nie funkcjonują w obszarze ,ja prawdziwego". Myślę, że wielu spośród nich ślepo naśladuje to, co ich otacza, i nie zadaje sobie pytania: „Kim jestem?”. Jak wynika z obserwacji, wielu użytkowników kreuje w sieci swój idealny wizerunek przez wzorowanie się na współczesnych trendach. Trudno stwierdzić, co jest ich celem. Wydaje się, że są to raczej intencje ukryte nawet przed nimi samymi. Ludzie jakby schematycznie nakładają najpierw maski, potem makijaże, żeby wreszcie nałożyć filtr na fotografię. Może ta próba udoskonalenia siebie, a także wpasowania w trendy i zyskania followersów ma na celu poczucie się kimś lepszym i piękniejszym. Dopóki wrzucanie zdjęć na swój profil jest zabawą i odbywa się od czasu do czasu, można uznać je za nieszkodliwe zjawisko. Jeśli jednak użytkownicy w trakcie każdego spotkania czy posiłku skupiają się na zrobieniu idealnej fotografii, działanie to może stać się szkodliwe zarówno dla nich, jak i dla ich odbiorców. Człowiek, zanurzając się w świecie Instagrama i tworząc w nim idealny profil własnej osoby, może tym samym kreować i wzmacniać „fałszywe ja”, odgradzając się od swojej prawdziwej tożsamości. Łatwo w ten sposób zapętlić się w idealnej wizji siebie, świata i innych osób, co odgradza człowieka od siebie samego, a także uniemożliwia przeżywanie siebie we wszystkich wymiarach relacji. 
W życiu współczesnego człowieka, który znajduje się na drodze odkrywania własnej tożsamości, zarówno w rzeczywistości realnej, jak i wirtualnej, zauważam dwie potrzeby: potrzebę ciszy przeznaczonej na spotkanie człowieka $z$ sobą i z Bogiem oraz potrzebę autentyczności. Można je powiązać zarówno z odbiorcą przekazów medialnych, jak i z twórcami tych przekazów. Mając na uwadze te konieczne do zaistnienia życia w obszarze ,ja prawdziwego" warunki, zauważam dwie następujące propozycje działań dla użytkowników social mediów.

Pierwszym z nich jest apelowanie o autentyczność, która pozwoli najpełniej i najszerzej ukazywać rzeczywistość ludzką taką, jaka ona jest, a co za tym idzie - przybliży człowieka do życia w „prawdziwym ja”. Niech zatem nie będzie to najbardziej kolorowy, modny, wpisujący się w obecne trendy wycinek rzeczywistości danej osoby, ulepszany za pomocą filtrów, modnego słownictwa itp., lecz prędzej niedoskonała i mniej popularna prawda o osobie.

Drugim rozwiązaniem jest odesłanie odbiorcy do ciszy. Działanie takie może wydawać się sprzeczne z celami autopromocji stosowanej w social mediach, zwłaszcza na Instagramie, jednak z pewnością wskazywałoby na dojrzałość autora profilu. Wymagałoby to jednak zadania sobie najpierw podstawowego pytania: co jest celem przekazywania przeze mnie takich, a nie innych treści? Czy biorę za nie odpowiedzialność? Co więcej, czy biorę współodpowiedzialność za odbiorców tych przekazów w aspekcie odbioru? Chodzi bowiem o to, by odbiorcy (inaczej fani czy też followersi) poznawali czy też podziwiali autentyczną osobę, żyjącą w obszarze ,ja prawdziwego”, a sami tylko się nią inspirowali i odchodzili do własnej rzeczywistości, do ciszy, do poszukiwania siebie samych, a później wracali w przestrzeń medialną jako osoby autentyczne, wnosząc w nią z kolei swoje „prawdziwe ja” będące niepowtarzalnym Bożym obrazem tych osób. 
$\mathrm{Na}$ sam koniec powyższych rozważań chciałabym podzielić się krótką refleksją. Wiele miesięcy temu podczas kilkugodzinnej podróży autobusem, gdy obserwowałam piękno i naturalność świata, w którym dane jest nam zaistnieć, przyszło mi do głowy pewne przemyślenie. Zawarłam je w pytaniach, którymi zakończę swój artykuł. Czym jest ciągle upragniona doskonałość wpisana w serce każdego człowieka? Czy bliżej jest jej do wszechobecnie promowanych ideałów, a może to nieustannie ukrywana za ekranem mediów i ,ja fałszywego" autentyczność każdej osoby ludzkiej?

\section{Wybrana bibliografia}

1. Benedykt XVI, Modlitwa miejscem odkrywania swojej tożsamośi - katecheza Benedykta XVI z 3 października 2012, https:// www.oaza.p1/cdm/strefa-modlitwy/katechezy-benedykta-xvi-o-modlitwie/45-modlitwa-miejscem-odkrywania-swojej-tozsamosci-katecheza-benedykta-xvi-z-3-pazdziernika-2012 (24.06.2019).

2. Benedykt XVI, Portale spotecznościowe: bramy prawdy i wiary; nowe przestrzenie dla ewangelizacji. Orędzie papieża Benedykta XVI na 47. Światowy Dzień Środków Spotecznego Przekazu, Watykan 2013, https://www.paulus.org.pl/220,47-sdssp-benedykt-xvi-2013 (24.06.2019).

3. Co to jest Instagram? Powstanie, rozwój aplikacji. Rejestracja, https://www.erainformatyki.pl/instagram.html (23.10.2019).

4. Dylematy tożsamości. Stare $i$ nowe konteksty socjalizacji, red. Z. Pucek, Kraków 2007.

5. Franciszek, Posynodalna adhortacja apostolska "Christus vivit”. Do mtodych i catego Ludu Bożego, Kraków 2019.

6. Gajda M., Gajda M., Rozwój. Jak wspótpracować z taskq??, Szczecin 2012. 
7. Keating T., Fatszywe „ja” - prawdziwe ,ja”, http://www.wccm. pl/index.php?id=441 (22.06.2019).

8. Klimczak P., Chrystologia 11. Chrystus w Ewangelii śrw. Jana. Cz. II: Formuty „Ja jestem”, http://www.szkolateologii.dominikanie.p1/summa/chrystologia-11-chrystus-w-ewangelii-sw-jana-cz-ii-formuly-ja-jestem/ (22.06.2019).

9. Pismo Święte Starego i Nowego Testamentu w przektadzie z języków oryginalnych [Biblia Tysiąclecia], oprac. zespół biblistów polskich z inicjatywy benedyktynów tynieckich, Poznań 1991.

10. Półtawska W., Beskidzkie rekolekcje. Dzieje przyjaźni księdza Karola Wojtyty z rodzinq Póttawskich, Częstochowa 2009.

11. Rozumienie siebie... czyli w jaki sposób poznajemy samych siebie, https://ssl-kolegia.sgh.waw.pl/p1/KES/struktura/IFSISE/ struktura/ZS/zaklad/sklad/Documents/5.Rozumienie_siebie. pdf (24.10.2019).

12. Rybicka D., Mtodzi Jana Pawta II, https://www.youtube.com/ watch? $=r \operatorname{Im} 6 \mathrm{eBROEdU}(22.06 .2019)$.

13. Tomczak M., Odkryć wtasna tożsamość - to bardzo trudne zadanie..., https://www.deon.pl/slub/homilie-slubne/art,2, odkryc-wlasna-tozsamosc-to-bardzo-trudne-zadanie-.html (24.06.2019).

14. W poszukiwaniu wtasnej tożsamości, fragment książki Jacques'a Philippe'a Gdybyś znata dar Boży. Nauka przyjmowania, https://info.dominikanie.pl/2017/10/w-poszukiwaniu-wlasnej-tozsamosci/ (24.06.2019).

15. Zaplatani w sieci. Spoteczeństwo wobec wyzwań nowych mediów, red. K. Piech i in., Toruń 2017. 